\title{
Do Tying, Bundling, and Other Purchase Restraints Increase Product Quality?
}

\section{Citation}

Kathryn E. Spier \& James D. Dana, Jr., Do Tying, Bundling, and Other Purchase Restraints Increase Product Quality?, Int'l J. Indus. Org. (2015).

\section{Published Version}

http://dx.doi.org/10.1016/j.ijindorg.2015.03.005

\section{Permanent link}

http://nrs.harvard.edu/urn-3:HUL.InstRepos:34816656

\section{Terms of Use}

This article was downloaded from Harvard University's DASH repository, and is made available under the terms and conditions applicable to Open Access Policy Articles, as set forth at http:// nrs.harvard.edu/urn-3:HUL.InstRepos:dash.current.terms-of-use\#OAP

\section{Share Your Story}

The Harvard community has made this article openly available.

Please share how this access benefits you. Submit a story.

Accessibility 


\title{
Do Tying, Bundling, and Other Purchase Restraints Increase Product Quality?*
}

\author{
James D. Dana, Jr. \\ Northeastern University \\ 360 Huntington Avenue \\ Boston, MA 02115 \\ j.dana@neu.edu
}

\author{
Kathryn E. Spier \\ Harvard Law School \\ 1563 Massachusetts Avenue \\ Cambridge, MA 02138 \\ kspier@law.harvard.edu
}

March 30, 2015

\begin{abstract}
Tying, bundling, minimum purchase requirements, loyalty discounts, exclusive dealing, and other purchase restraints can create stronger incentives for firms to invest in product quality. In our first example, the firm sells a durable experience good and a complementary non-durable good to a representative consumer. Tying shifts profits from the durable to the non-durable good, making profits more sensitive to the consumer's experience. In our second example, the firm sells a single experience good to consumers with heterogeneous demands. Minimum purchase requirements screen out the low-volume consumers who would otherwise free ride on the superior monitoring of the high-volume consumers. The examples illustrate that purchase restraints can increase both firm profits and consumer surplus by making firm profits more sensitive to consumer experience, either directly by giving the consumer more control over the stream of profits or indirectly by constraining consumers to monitor more intensively.
\end{abstract}

\footnotetext{
${ }^{*}$ We would like to thank our editor, Heski Bar-Isaac, two anonymous referees, Louis Kaplow, Barry Nalebuff, Marco Ottaviani, Martin Peitz, Patrick Rey, and Mike Whinston, as well as seminar participants at the E.A.R.I.E. 2014 Annual Conference in Milan, Italy for helpful comments. James Dana acknowledges financial support from Northeastern University, Harvard Business School, and Yale University. Kathryn Spier acknowledges financial support from the John M. Olin Center for Law, Economics, and Business at the Harvard Law School and NSF Grant SES-1155761. Some of the content of this paper and it's companion paper (Dana and Spier, 2014) was previously circulated in our unpublished working paper titled "Product Bundling and Reputation."
} 


\section{Introduction}

Why do firms constrain consumer choice by physically bundling their products together or by contractually mandating their products be jointly purchased? In the law and economics and industrial organization literatures, most research on product bundling and product tying focuses on price discrimination or market foreclosure. ${ }^{1}$ In antitrust litigation, however, firms often defend these practices as reducing costs or enhancing their ability to control product quality and maintain strong reputations in the marketplace. ${ }^{2}$ While academics widely acknowledge the existence of economies of scope that lower costs or increase observable quality, the academic literature on the potential for bundling and tying to increase unobservable quality (i.e., experience goods) is relative small. ${ }^{3}$ In this paper, we describe the ways in which purchase restraints - including tying, bundling, quantity forcing, volume discounts, and loyalty programs - can create stronger incentives for firms to invest in product quality, and can increase both profit and consumer surplus.

Specifically, consider the product quality decision of single firm that sells experience goods to consumers. ${ }^{4}$ Since consumers do not directly observe the quality of the firm's products at the time of sale, the firm is tempted to produce and sell a lower quality product to reduce its production costs. Consumers receive imperfect private signals that are correlated with the quality of their purchases, and learn gradually about the firm's effort decisions. If the consumers purchase the good only once, or purchase it relatively infrequently, then high quality cannot be sustained in equilib-

\footnotetext{
${ }^{1}$ See Rey and Tirole (2007) and Nalebuff (2008) for overviews of the literature. Famous lawsuits on metering and price discrimination include Motion Picture Patents v. Universal Film, 243 U.S. 502, 518 (1917) and Morton Salt Co. v. G.S. Suppinger Co., 314 U.S. 488, 490 (1942). Cases on market foreclosure include United States v. Microsoft Corporation 253 F.3d 34 (D.C. Cir. 2001).

${ }^{2} \mathrm{Hilti}$, a leading producer of nail guns and supplies, defended its bundling practices saying that the use of a competitor's nails would "give rise to uncertain fixing reliability and, consequently, safety risks in load bearing applications." Press Release, Hilti Ltd., Warning: Profix Nails Used in Hilti DX Tools (June 30, 1988). See Case T-30/89, Hilti AG v. Comm'n, 1991 E.C.R. II-1439. See the more general discussion in Kaplow (1985, p. 545 at N. 121), Brief for Appellants at 13, 34, International Salt Co. v. United States, 332 U.S. 392 (1947); Brief for Appellants at 8-16, International Bus. Mach. Corp. v. United States, 298 U.S. 131 (1936); Brief for Appellants, Vol. 1, at 221-26, United Shoe Mach. Co. v. United States, 258 U.S. 451 (1922); Brief for Appellees at 13, Henry v. A.B. Dick Co., 224 U.S. 1 (1912).

${ }^{3}$ See Kaplow (1985, p. 545 at N. 121), Nalebuff (2008, p. 1887), Katz (1989, p. 685-689), Bork (1978, 379-381). To the best of our knowledge, the only academic papers on this topic are Schwartz and Werden (1996), Iacobucci (2003), and our related paper, Dana and Spier (2014).

${ }^{4}$ Our examples are also useful for understanding restraints when an upstream firm is selling to multiple independent downstream firms (see Katz, 1989, and Rey and Verge, 2010 for general discussions of vertical restraints).
} 
rium. But with more frequent purchases, the firm has less incentive to shirk and high quality may be sustained (Klein and Leffler, 1981). Using two simple examples, we illustrate that tying, bundling and other purchase restraints can have a similar effect to increasing purchase frequency and can help the firm to sustain high quality in a broader range of circumstances than could be achieved otherwise.

In our first example, the firm sells two products, a durable experience good that is purchased infrequently, and a complementary non-durable good that is purchased in every period, to a representative consumer. The non-durable good is of known quality, and is also available from a competitive market. Absent tying, the incentive for the firm to cheat and reduce the quality of the durable good is strong: since the consumer purchases the durable good infrequently, the reputation mechanism works poorly. If the firm ties the products, it charges a lower price for the durable good but a higher-than-market price for the complementary non-durable good. Through this scheme, bundling or tying creates a stream of rents that will accrue to the firm if and only if the consumer remains satisfied with his or her purchases. ${ }^{5}$

In our second example, the firm sells a single non-durable good to a population of consumers with heterogeneous demands. ${ }^{6}$ Some consumers would like to purchase large volumes, while others would prefer to purchase small volumes. The consumers who purchase large volumes are more effective at monitoring the firm, since they have more opportunities to detect low quality. Consumers who demand small volumes monitor less effectively, and free ride on the monitoring done by the high-volume consumers. Importantly, we show that the presence of too many of these free-riding consumers erodes the firm's incentives to invest in product quality and makes the provision of a high quality product unsustainable. ${ }^{7}$ Minimum purchase requirements, quantity forcing, and other purchase restraints serve to exclude these low-volume consumers from the market, increasing the average speed of consumer learning and

\footnotetext{
${ }^{5}$ See Schwartz and Werden (1996) for a closely related signaling theory. Alternatively, the firm may create a stream of rents by leasing the durable good. As here, leasing converts the profit on an infrequently purchased durable to a frequently purchased non-durable. This empowers consumers to punish the firm when quality is low, which in turn creates stronger incentives for the firms. A returns contract, or unconditional warranty, in which the consumer receives a refund upon the return of the durable is another alternative.

${ }^{6}$ The example here is simpler, but more stylized, than the model in Dana and Spier (2014), which considers a more general environment with multiple products.

${ }^{7}$ Consumers are not choosing how much to invest in monitoring. Instead monitoring is just a byproduct of consumption. But monitoring can still be thought of as a public good. However if there were only one consumer, that consumer would internalize the impact of his or her purchase decision on the firm's incentives. When consumers are small they free ride in the sense that they ignore the impact of their consumption choice on the firm's incentives to produce a high-quality product.
} 
the firm's incentive to invest. ${ }^{8}$

\section{Using Purchase Restraints To Create A Stream of Rents}

To illustrate the idea of this section, suppose that a firm produces two goods: a longlasting printer and single-period-use ink cartridges. The printer is an experience good in the sense that its quality is not directly observed by consumers at the time of sale. The ink cartridge, however, has known quality and is supplied by a competitive market. Absent bundling or tying, consumers are free to buy ink cartridges in a competitive market at marginal cost. The moral hazard problem is potentially severe in this environment. Since consumers purchase printers infrequently, the firm has an incentive to cheat and reduce the quality of the printers. Thus, absent bundling, the reputation mechanism is ineffective. With bundling, however, the firm has a much stronger incentive to produce high-quality printers. By requiring consumers to purchase ink from the firm at a marked-up price, the firm gives consumers a tool with which to punish the firm for producing low-quality printers. When a customer discovers that the quality of the printer is low, the consumer will rationally cut back on ink purchases and deprive the firm of its profit margins.

In addition to printers and ink, there are many examples of firms that sell both durable experience goods and complementary non-durables products and appear to earn higher markups on the tied non-durable. Razors are often sold along with higher markup razor blades. ${ }^{9}$ Computer hardware can be bundled with software (particularly video consoles and video games) and hardware accessories (power cords and adapters). And many durable goods are loosely "bundled" with service agreements (often, consumers face penalties for obtaining service from third parties). Historically, there have been many antitrust lawsuits that involved the tying of a consumable product or service to that of a durable good, including the well-known IBM tabulating cards case. ${ }^{10}$

\footnotetext{
${ }^{8}$ In situations where a firm sells multiple experience goods, these insights imply that product-line forcing intensifies the monitoring by consumers and speeds the rate of consumer learning, providing additional incentives for high quality. See the more general multiproduct model in Dana and Spier (2014).

${ }^{9}$ An alternative explanation for this type of tying is that it facilitates price discrimination, and this explanation would also predict that tying leads to higher markups on the tied non-durable and lower markups on the durable. It is not clear how one would empirically distinguish between these motives for tying.

${ }^{10}$ In the $1930 \mathrm{~s}$, IBM was prosecuted for its practice of tying paper tabulating cards to that of
} 
Consider a simple game with a single firm and a representative consumer (and a competitive fringe that exists absent bundling). The firm produces two products: a durable experience good $A$ and a non-durable good $B$. The consumer derives no value from product $A$ without consuming product $B$, and vice versa. The firm's cost of producing a high-quality durable good is $c_{A}$, and the cost of producing a low quality durable is 0 . The unit cost of producing the non-durable good, which is of known quality, is $c_{B}$. We let the prices be $p_{A}$ and $p_{B}$, respectively. If the consumer owns a high-quality durable good, the consumer's demand for the non-durable good in each period is given by $D\left(p_{B}\right) \cdot{ }^{11}$ If the consumer owns a low-quality durable good, their expected value of consumption of the non-durable good is zero, or negative. This assumption implies that a low-quality good is not sold when the high-quality good cannot be sustained and is made for convenience and notational simplicity.

If the firm ties its products, consumers who buy the durable from the firm must also buy the non-durable from the firm, even if it is available at a lower price elsewhere. However, consumers are unconstrained in the amount of the non-durable they consume. This model of tying is often called "metered tying" because the level of consumption of the non-durable good can serve as a meter for how much consumers value the durable good (see for example Elhauge and Nalebuff, 2014). ${ }^{12}$ However, in our representative consumer setting, we can ignore price discrimination as a motive for metered tying.

The timing of the game is simple. At time 0 , the firm decides whether to tie its goods (thereby requiring consumers to buy the non-durable good from the firm),

tabulating machines and General Motors was prosecuted for its requirement that its automobile dealers only use genuine General Motors parts in the repairs of its cars. IBM v. United States (298 U.S. 131 [1936]). Pick Mfg. Co. v. General Motors Corp. et al. (80 F. 2d 641 [7th Cir. 1935]). IBM and GM argued that competitors would supply lower quality non-durables, damaging the reputation for their durable product, which obviously differs from our simple stylized example. In 1991, Hilti, a market leader in building materials, was fined 6 million Euros for tying the sales of nails and cartridge strips to the sales of its nail guns (see references in footnote 2 above). Around the same time, the Van den Bergh (VB) Foods' practice of giving ice cream freezers to retailers for free but requiring them to stock only VB ice cream constituted illegal tying. (See European Commission: Van den Bergh Foods Ltd, Cases IV/34.073, IV/34.395 and IV/ 35.436; Case T-65/98 Van den Bergh Foods Ltd v Commission [2003] ECR II-4563.)

${ }^{11}$ Note that the per-period demand function depends only on the price of the non-durable good, $p_{B}$, because the price of the durable good, $p_{A}$, is sunk.

${ }^{12} \mathrm{An}$ important benefit to the firm of metered tying is that it facilitates price discrimination. Elhauge and Nalebuff (2014) show in general that metered tying can only increase social welfare if it leads to greater sales of the durable good. In our example, metered tying is procompetitive because it increases unobservable product quality of the durable, increases total sales of the durable, and increases total welfare. 
commits to prices $p_{A}$ and $p_{B}$, and privately chooses the quality of the durable good. ${ }^{13}$ Next, the consumer decides whether to purchase the durable good from the firm. At time 1, and in each period thereafter, the consumer decides how many units of the non-durable good to buy. Under these assumptions, the consumer's per-period surplus, assuming the quality of the durable good is high, is

$$
C S\left(p_{B}\right)=\int_{p_{B}}^{\bar{p}} D(p) d p
$$

and the per-period producer surplus is

$$
P S\left(p_{B}\right)=D\left(p_{B}\right)\left(p_{B}-c_{B}\right) .
$$

As a benchmark, consider the optimal complete-information prices, that is, the prices the firm would charge if the quality of the durable good was observed by the consumer at the time of purchase, so there was no moral hazard problem. The firm's profits would be maximized by setting the price of the non-durable good equal to $p_{B}^{*}=c_{B}$ and charging $p_{A}^{*}=C S\left(c_{B}\right) /(1-\delta)$ for the durable good. In other words, the firm charges marginal cost for the non-durable good, thereby eliminating distortions, and extracts all of the consumer surplus up front through the lump-sum charge for the durable good. Since the non-durable good would be priced at cost, the firm could do just as well if the competitive fringe were allowed to supply the non-durable good. With observable quality, bundling has no impact on firm profit or social welfare.

Now suppose instead that the quality of the durable good is not observed by consumers at the time of sale. We assume that when the durable good is of low quality, the expected value consumers receive from consuming the durable and nondurable products is zero, but the consumer does not observe this valuation directly. Instead, the consumer receives a private signal in each period that is correlated with the unobserved quality of the durable good. If the durable good is of high quality, the consumer never receives a negative signal. If the durable good is of low quality, then in each period the consumer receives a negative signal with probability $1-\pi .{ }^{14}$ For example, consumers may purchase "high-quality" building materials in the expectation that they will increase their home's durability (and its future resale

\footnotetext{
${ }^{13}$ In contrast to this moral hazard argument, Schwartz and Werden (1996) offer a similar asymmetric information model to argue that such tying allows a firm to signal that its products are of high quality.

${ }^{14}$ While there are variety of utility and information foundations for these assumptions, one simple set of underlying assumptions is that the value to a consumer of the high-quality good, and the value to the consumer the low-quality good when a negative signal is not observed, is $\int_{0}^{q_{B}} P(q) d q$ where $P(q)$ is the inverse demand associated with $D(p)$, and that $\int_{0}^{q_{B}} P(q)-H$ is the value to the
} 
value), yet when the quality is actually low they may observe a negative signal of the true quality long before the quality it directly influences their utility.

Since a high-quality durable good never produces a negative signal, a consumer who initially believes the quality of the durable good is high will continue to purchase $D\left(p_{B}\right)$ units of the non-durable good in each period until a negative signal is received. Note that a fraction $1-\pi$ of consumers leave the market each period when the durable good quality is low, but a fraction $\pi$ stay, so the firm would enjoy a shrinking stream of producer surplus. ${ }^{15}$

Now suppose that the firm charges prices $p_{A}$ for the durable good, charges $p_{B}$ for the non-durable good, and requires consumers who purchase the durable good to purchase the non-durable good exclusively from the firm. A high-quality equilibrium is sustainable if only if the firm's incentive compatibility constraint is satisfied:

$$
p_{A}-c_{A}+\frac{P S\left(p_{B}\right)}{1-\delta} \geq p_{A}+\frac{P S\left(p_{B}\right)}{1-\delta \pi} .
$$

The left-hand side is the producer surplus when the firm produces a high-quality durable, and the right-hand side is the producer surplus if the firm cheats and produces a low-quality durable. In the latter case, the firm saves its production $\operatorname{cost} c_{A}$ but loses sales of the non-durable as customers observe negative signals over time.

We can rewrite the firm's incentive compatibility constraint as:

$$
P S\left(p_{B}\right)\left(\frac{1}{1-\delta}-\frac{1}{1-\delta \pi}\right) \geq c_{A} .
$$

The expression in brackets on the left-hand side is strictly positive for all $\pi<1$. Note that incentive compatibility cannot be satisfied at the complete information prices; when the price of the non-durable is equal to marginal cost, $p_{B}^{*}=c_{B}$, then the producer surplus from the sale of the non-durable is zero, $P S\left(p_{B}^{*}\right)=0$. To

consumer of the low-quality good when a negative signal is observed, where $H$ is a harm associated with the negative signal that occurs with probability $1-\pi$. Setting $H=\left(\int_{0}^{q_{B}^{*}} P(q) d q\right) /(1-\pi)$ implies that the expected utility from a low quality good is 0 each period when the price is $p_{B}=c_{B}$ so consumption is $q_{B}^{*}=D\left(c_{B}\right)$, and strictly negative at any higher price, which is consistent with our assumptions. But our assumptions are also consistent with the benefits of the product not being realized until the future, and the signal being purely information and not a harm.

${ }^{15}$ If the firm shirks at time 0 and produces a low-quality durable good, the probability that the consumer will purchase the non-durable good in period $t$ is $\pi^{t-1}$. Note that for simplicity we assume here that the probability of seeing a negative signal each period is independent of the quantity of the non-durable consumed. In the next section, we allow for the probability of a negative signal to increase with the quantity purchased, and show that this provides a rationale for bundled discounts and loyalty program. 
achieve incentive compatibility, the firm must raise the price $p_{B}$ above marginal cost, but this is distortionary and inefficient.

Proposition 1 A high-quality equilibrium exists if and only if there exists some price $p_{B}$ at which $\left(\mathrm{IC}_{1}\right)$ is satisfied. A low-quality equilibrium with zero sales always exists. Producer surplus and total surplus are higher in any high-quality equilibrium than in the low-quality equilibrium (consumer surplus is zero in either case). When it exists, the most profitable high-quality equilibrium is one in which $p_{B}^{* *}$ makes $\left(\mathrm{IC}_{1}\right)$ hold with equality, $p_{B}^{* *}>p_{B}^{*}$, and $p_{A}^{* *}=C S\left(p_{B}^{* *}\right) /(1-\delta)<p_{A}^{*}$.

If it is possible, the firm will raise the price of the non-durable good to a level $p_{B}^{* *}>p_{B}^{*}=c_{B}$ that is just sufficient to satisfy the incentive compatibility constraint. So $p_{B}^{* *}$ is defined as the lowest price that makes $\left(\mathrm{IC}_{1}\right)$ hold with equality. If high quality is feasible, the firm will then set the price of the durable good to extract all consumer surplus, $p_{A}^{* *}=C S\left(p_{B}^{* *}\right) /(1-\delta)<p_{A}^{*}$. If high quality is not feasible (i.e., no price $p_{B}^{* *}$ exists that satisfies the incentive constraint) then the firm will produce a low quality durable good or not produce at all.

While the model is simple, note that a high-quality equilibrium is more likely to exist the higher is the discount factor and the greater is the total surplus (greater demand and lower cost). And naturally these factors also increase welfare (directly and indirectly through their impact on quality and reducing the distortion in price). The high-quality equilibrium is also more likely to exist when consumers have better information about quality (i.e., higher $\pi$ ).

Of course, another way that the firm can convert the rents from its sale of the high-quality durable good into a stream of rents that the consumer can use to punish bad outcomes is by leasing the durable good. Lease or rental contracts, if they allow the consumers to cancel their contract and return the good at anytime, are another commitment device that aligns the firm's and consumers' incentives, and leasing does not distort consumption of the non-durable good. However the transactions cost of leasing could be large. First, consumers may decline to make timely rental payments, requiring the use of collection agencies or repossession of the durable good. Second, as is typical in rental markets, consumers may take too little care in their handling of the durable good, causing its resale value to decline. However it is also the case that transactions costs could also arise with tying and bundling. For instance, consumers may have attempt to purchase the non-durable good from unauthorized (and cheaper) suppliers, though firms might try to mitigate this behavior by voiding any warranties or by taking legal action against the rogue suppliers. 


\section{Using Purchase Restraints to Facilitate Con- sumer Monitoring}

In reality, consumers are heterogeneous and learn about a firm's product quality in different ways and at different rates. Consumers who purchase a full product line from a particular firm, or consumers who buy large quantities of a particular product, will have more opportunities to detect problems and will therefore tend to learn more quickly. Customers who purchase more selectively, or in small quantities, will tend to learn more slowly. Importantly, the presence of slow learners can compromise the firm's incentives to produce high-quality experience goods. Slow-learning consumers will free ride on the superior monitoring ability of consumers who purchase higher volumes or more complete product lines. If there are too many slow-learning consumers in the market, the firm may have an insufficient incentive to provide high-quality products. We argue that bundling, tying, and other purchase restrictions prevent free-riding by slow-learning customers. This leads to higher product quality and is both privately and socially optimal.

Minimum purchase restraints and related mechanisms (loyalty programs, exclusive dealing, product line forcing, and product variety restrictions) are very common. In the mid-1990s, Microsoft was prosecuted for several business practices, including its licensing agreements which required PC manufacturers to install Microsoft's operating system on a minimum number of computers. ${ }^{16}$ More recently, Sanofi-Aventis faced antitrust charges for its loyalty discounts on Lovenox, a patented anticoagulant drug that is used in hospital settings. ${ }^{17}$ Specifically, Sanofi-Aventis offered hospitals discounts of up to thirty percent if at least ninety percent of their anticoagulant purchases were from Sanofi-Aventis. Our theory suggests that minimum purchase requirements, or loyalty discounts, might induce more intense monitoring by buyers and create stronger incentives for firms. Note that our theory may be particularly relevant for newer products about which there is greater asymmetric information.

Specifically, we consider a market for a single good where consumers must decide how many units to purchase in each period. Each consumer places valuation $v$ on one unit of a high-quality good and valuation 0 on one unit of the low-quality good. The consumers differ from each other in how many units they demand, which we denote by $x$, where $h(x)$ is a smooth (no mass points) density function on $[0, \bar{x}]$.

\footnotetext{
${ }^{16}$ See United States v. Microsoft Corp., 1995-2 Trade Cases para. 71,097 (D.D.C. 1995). 3M, the producer of Scotch tape, faced scrutiny for its discounts to office supply stores to purchase fewer products from 3M's competitors. LePage's Inc. v. 3M Co., 324 F.3d (3d Cir. 2003), cert. denied, 124 S. Ct. 2932 (2004).

${ }^{17}$ Eisai Inc. V. Sanofi-Aventis U.S., LLC, No. 08-4168 (MLC)(D.N.J. Mar. 28, 2014.
} 
So $\int_{0}^{\bar{x}} h(x) d x$ is the total number of consumers, and the total potential demand is $\int_{0}^{\bar{x}} x h(x) d x$, both of which we assume are finite. We assume that a high-quality good has unit production cost $c$, and the low-quality good has unit production cost 0 .

As in the previous section, we assume that high-quality products never generate negative signals. Low-quality products do generate negative signals, and the likelihood that a consumer who consumes $x$ units observes a negative signal is $1-\pi(x)$, where $\pi(x)$ is differentiable, $\pi^{\prime}(x)<0$, and $\pi(0)=1$. When the quality is low, consumers who consume more units of the good are more likely to observe a bad signal and are thus more effective at monitoring the firm. ${ }^{18}$ Consumers do not directly choose how much to monitor in our model. Instead, the intensity of monitoring by consumers is a by-product of higher levels of consumption. Our model is related to more general models of responses to heterogeneous monitoring analyzed in Bar-Isaac and Deb (2014) and Bar-Isaac, Caruana and Cuat (2012).

The firm chooses the price $p$ and the minimum order size $m$ to maximize its profits subject to an incentive compatibility constraint.

To simplify the exposition and analysis, we make the following assumption: ${ }^{19}$

Assumption 1 A consumer of type $x$ who purchases $m>x$ units of the good uses $x$ of those units and does not use the additional $m-x$ purchased units.

Assumption 1 implies that a consumer who is forced to purchase more units than he or she really needs observes a product failure with probability $1-\pi(x)$, not $1-\pi(m)$. This implies that quantity forcing does not make individual consumers into better monitors, so Assumption 1 is therefore a conservative assumption - the benefit of minimum purchase restraints would be even greater if these consumers consumed the additional units. Quantity forcing does improve the average level of monitoring, however, since it essentially forces low-volume consumers to leave the market. ${ }^{20}$

\footnotetext{
${ }^{18}$ One interpretation (but not the only one) of our assumptions is that $1-\pi(x)$ is the probability that a type $x$ consumer suffers a harm, $H(x)=v x /(1-\pi(x))$, when consuming $x$ low-quality goods. If quality is low, the consumer gets $v x$ with probability $\pi(x)$ and $v x-H(x)$ with probability $1-\pi(x)$. It follows that the expected utility from a low quality good is 0 , the probability of a negative signal is $1-\pi(x)$, and the expected utility from a high-quality good is $v x$. It is easy to see how $H(x)$ can be proportional to $x$. For example, if $H=v /(1-\pi(x))$ is the harm when a single unit of the product fails and product failures are perfectly correlated, then when a failure occurs, $H(x)=H x=v x /(1-\pi(x))$.

${ }^{19}$ We also assume consumers purchase $x$ units when they are indifferent. Otherwise, in a mechanism design framework, the firm could implement the first best outcome simply by setting $p=v$ and telling consumers to purchase the good if $x \geq m$ and not to purchase if $x<m$. Alternatively, imagine the firm is constrained to give consumers some positive rents.

${ }^{20}$ Alternatively, we could assume instead that a consumer of type $x$ who buys $m$ units receives a
} 
In the Appendix, we prove that under Assumption 1, the firm's optimal price is $p=v$. So the firm's problem is to choose the minimum order size, $m$, to maximize its profits subject to the incentive compatibility constraint,

or

$$
\int_{m}^{\bar{x}}\left(\frac{v-c}{1-\delta}\right) x h(x) d x \geq \int_{m}^{\bar{x}}\left(\frac{v}{1-\delta \pi(x)}\right) x h(x) d x,
$$

$$
\Delta(m)=\int_{m}^{\bar{x}}\left(\frac{v-c}{1-\delta}-\frac{v}{1-\delta \pi(x)}\right) x h(x) d x \geq 0 .
$$

Consider the large term in brackets inside the integral in Equation $\left(\mathrm{IC}_{2}\right)$. This expression is increasing in $x$ since $\pi^{\prime}(x)<0$ - consumers who purchase in larger quantities are better monitors. Since $\pi(0)=1$, this expression is clearly strictly negative when $x=0 .{ }^{21}$

Proposition 2 If $\Delta(\bar{x})>0$, then an equilibrium exists in which the firm sells a high quality good, and if $\Delta(0)<0$ then every high-quality equilibrium has a minimum purchase requirement. Producer surplus and total surplus (welfare) in the high-quality equilibrium are higher (consumer surplus is zero in either case). If $\Delta(\bar{x})>0$ and $\Delta(0)<0$, then the most profitable high-quality equilibrium is the one in which the minimum purchase restraint is given by $\Delta\left(m^{*}\right)=0$, that is, the incentive compatibility constraint, $\left(I C_{2}\right)$, holds with equality.

Since $\pi(0)=1, \Delta(0)<0$ if there are sufficiently many consumers with small demands (low $x$ ). And $\Delta(\bar{x})>0$ as long as type $\bar{x}$ consumers are sufficiently good monitors $(\pi(\bar{x})$ is sufficiently small).

While the model is again simple, note that as before a high-quality equilibrium is more likely to exist the higher is the discount factor and the greater is the total surplus (the greater is the valuation $v$ and the lower is the cost $c$ ). And naturally these also increase welfare (directly and through their impact on quality and reducing the distortion in price). A high-quality equilibrium is also more likely to exist the better is consumer's information about quality (higher $\pi$ ).

While we don't typically see firms bragging in their marketing campaigns that they exclude small orders to convince customers that quality is high, this model is nevertheless consistent with the claims firms make about bundling or tying related

negative signal with probability $1-\pi(m)$. In this case $p<v$ may be optimal, but it still follows that $m>0$ is optimal. However, now quantity forcing excludes some consumers and increases the monitoring activity of others. More details of this case are described in the Appendix.

${ }^{21}$ When $x=0$, then $\pi(0)=1$, and the expression in brackets becomes $-c /(1-\delta)<0$. Continuity implies that this expression is also negative when $x$ is small. 
goods, and the logic of our argument generalizes to heterogeneous products. By consuming more products per period, consumers observe more signals of product quality. One subtle difference is that in a model with two different goods, the firm might choose the two qualities independently and consumers might rationally behave just as they would if the products were produced by different firms. However, as we show in Dana and Spier (2014), total surplus and firm profits are strictly higher in an equilibrium in which the firm shirks on the quality of all of its products whenever it shirks on the quality of one and in which consumers believe that the firm has shirked on the quality of all of its products if they learn it has shirked on the quality of one.

Also note that the firm might be able to use other restraints or other business strategies to increase monitoring. For example, the firm might use buyer groups, or other referral promotions, as a mechanism to get smaller buyers to share their information with each other.

Finally, it is worth noting that the results of this section can also hold in a model with homogenous consumers with downward sloping demands. Homogeneous consumers will also ignore the impact of their purchase decisions on the firm's incentives to produce high quality, so faced with linear prices, these consumers may purchase too few units of a product (or too narrow a selection of the firm's product line) for high quality to be sustainable. Even if there is just one consumer, this consumer will tend to consume to little (underinvest in monitoring) when the firm captures some or all of the surplus associated with high quality. However when consumers are homogeneous, the firm can induce higher consumption (better monitoring) with other types of purchase restraints, including volume discounts, two-part tariffs, and other forms of non-linear pricing.

\section{Concluding Remarks}

Many antitrust scholars and commentators have viewed the quality assurance defense with ambivalence. In his book, The Antitrust Paradox, (1978, p. 380), Robert Bork wrote "One wonders whether this justification for tying is not worthy of more respect than it has been accorded. The only ground for skepticism about this defense is the argument that the tie is unnecessary to the accomplishment of the purpose." As explained by Nalebuff (2009, p. 377), if "the primary good manufacturer's complementary or aftermarket products truly ensure quality, then customers should choose the firm's products without being forced to do so."

In rather stark contrast to this skepticism, we argue that the compulsion of a tied sale may be necessary - or even essential - for ensuring quality when product quality is not observable at the time of purchase. In our first example, absent a tie, consumers 
would rationally choose to forego the branded consumable product or service in favor of that supplied by the competitive market. This would compromise the firm's ex ante incentive to produce a high-quality durable good. In our second example, absent the tie, the consumers would purchase too little of the firm's products and thereby compromise their roles as monitors of product quality. The crucial insight is that consumers' incentives to monitor and punish are not socially optimal because of free riding, so the firm needs to use restraints, as opposed to financial incentives, to better align incentives.

It is worth mentioning that the specific mechanisms identified and studied in this paper have not, to our knowledge, been emphasized in antitrust litigation or competition policy cases. One reason for this is that firms may be reluctant to draw attention to the fact that their business practices are necessary to create an incentive to produce high quality products. First, this could potentially make consumers more concerned about product quality and the trustworthiness of the firms, and less rather than more willing to purchase the products. And second, these incentives may have been optimal ex ante, but to the extent the investment in a quality durable is sunk, the firm might not want to encourage to consumers or policy makers to take away those incentives ex post.

In Dana and Spier (2014) we analyze a more general model with two different but complementary products which fits many of the applications more closely. In that paper, we also consider the attribution problem, in which consumers who purchase products from different firms are unable to accurately attribute negative outcomes with individual products. We show that the social welfare justification for product bundling is even stronger in this context. We hope that this pair of papers will help to foster additional empirical and theoretical research into the potential social welfare benefits of purchase restraints. 


\section{References}

[1] Bar-Isaac, Heski, and Joyee Deb (2014) "(Good and Bad) Reputation for a Servant of Two Masters" American Economic Journal: Microeconomics, 6(4), 293-325.

[2] Bar-Isaac, Heski, Guillermo Caruana, and Vicente Cuat (2012) "Information gathering externalities in product markets" Journal of Industrial Economics, LX(1) 162-185.

[3] Bork, Robert (1978) The Antitrust Paradox: A Policy at War with Itself, New York: Basic Books, 1978.

[4] Dana, James D., Jr., and Kathryn E. Spier (2009) "Bundling and Firm Reputation," Harvard Law and Economics Discussion Paper No. 649.

[5] Dana, James D., Jr., and Kathryn E. Spier (2014) "Bundling and Quality Assurance," working paper.

[6] Elhauge, E. and B. Nalebuff (2014) "The Welfare Effects of Metered Ties," working paper.

[7] Iacobucci, Edward M. (2003) "Tying as Quality Control: A Legal and Economic Analysis," Journal of Legal Studies, 32, 435-464.

[8] Kaplow, Louis (1985) "Extension of Monopoly Power Through Leverage," Columbia Law Review, 85, 515-556.

[9] Katz, Michael (1989) "Vertical Contractual Relations," in Handbook of Industrial Organization, ed. by R. Schmalensee, and R. Willig. 655-721. NorthHolland, Amsterdam.

[10] Klein, B., and K. Leffler (1981) "The Role of Market Forces in Assuring Contractual Performance," Journal of Political Economy, 89(4), 615-641.

[11] Nalebuff, B. (2004) "Bundling as an Entry Barrier," Quarterly Journal of Economics, 119(1), 159-187.

[12] Nalebuff, B. (2008) "Bundling and Antitrust," in Issues in Competition Law and Policy, edited by D. Collins, 1881-1910. Washington, DC: ABA Section of Antitrust Law. 
[13] Nalefuff, B. (2009) "Unfit to Be Tied: An Analysis of Trident v. Independent Ink (2006)," in The Antitrust Revolution, 5th edition, ed. by J. Kwoka, and L. White, 365-88. New York: Oxford University Press.

[14] Rey, Patrick, and Thibaud Verge (2010) "Economics of Vertical Restraints," in Handbook of Antitrust Economics, ed. by Paulo Buccirossi, MIT Press, Cambridge.

[15] Rey, Patrick, and Jean Tirole (2007) "A Primer on Foreclosure," in Handbook of Industrial Organization: Volume III, ed. by M. Armstrong, and R. Porter. North-Holland, Amsterdam.

[16] Schwartz, Marius and Gregory Werden (1996) "A Quality-Signaling Rationale for Aftermarket Tying," Antitrust Law Journal, 64, 387-404. 


\section{Appendix}

\section{Proof of Proposition 2:}

In this appendix, we show that under Assumption 1 the solution to the minimum order size problem satisfies $p=v$, an omitted step in the proof that the optimal order size is strictly positive under Assumption 1. We also prove that the minimum order size is strictly positive even when Assumption 1 is relaxed. The rest of the proof of Proposition 1 is in the text of the paper.

A type $x$ consumer is willing to pay $v x$ for $x$ or more units, so consumers of type $x<m$ are willing to purchase $m$ units if the price satisfies $p m \leq v x$, or $x \geq \frac{p}{v} m$. The firm chooses $p \leq v$ and $m \leq \bar{x}$ to maximize it profits,

$$
\int_{\frac{p}{v} m}^{m}\left(\frac{p-c}{1-\delta}\right) m h(x) d x+\int_{m}^{\bar{x}}\left(\frac{p-c}{1-\delta}\right) x h(x) d x,
$$

with respect to $p$ and $m$, and subject to its incentive compatibility constraint,

$$
\begin{aligned}
\int_{\frac{p}{v} m}^{m}\left(\frac{p-c}{1-\delta}\right) & m h(x) d x+\int_{m}^{\bar{x}}\left(\frac{p-c}{1-\delta}\right) x h(x) d x \geq \\
& \int_{\frac{p}{v} m}^{m}\left(\frac{p}{1-\delta \pi(x, m)}\right) m h(x) d x+\int_{m}^{\bar{x}}\left(\frac{p}{1-\delta \pi(x, x)}\right) x h(x) d x,
\end{aligned}
$$

where $1-\pi(x, y)$ is the probability a type $x$ consumer observes a negative signal when purchasing $y$ low-quality units. The first term of the objective function is the profit from types for whom $x<m$, but nevertheless choose to buy $m$ units, and the second term is the profit from types who are unconstrained by the minimum purchase requirement, $m$.

We now perform a change of variables, and let $z=p m$. Substituting $p m=z$ and $m=z / p$ in the expressions above, the firm chooses $p \leq v$ and $z \leq p \bar{x}$ to maximize

$$
\int_{z / v}^{z / p}\left(\frac{z-c z / p}{1-\delta}\right) h(x) d x+\int_{z / p}^{\bar{x}}\left(\frac{p-c}{1-\delta}\right) x h(x) d x
$$

subject to

$$
\begin{aligned}
\int_{z / v}^{z / p}\left(\frac{z-c z / p}{1-\delta}\right) h(x) d x+\int_{z / p}^{\bar{x}}\left(\frac{p x-c x}{1-\delta}\right) h(x) d x \\
\quad-\int_{z / v}^{z / p}\left(\frac{z}{1-\delta \pi(x, z / p)}\right) h(x) d x-\int_{z / p}^{\bar{x}}\left(\frac{p x}{1-\delta \pi(x, x)}\right) h(x) d x \geq 0 .
\end{aligned}
$$


Taking the derivative of the objective function with respect to $p$ yields

$$
\int_{z / v}^{z / p}\left(\frac{c z / p^{2}}{1-\delta}\right) h(x) d x+\int_{z / p}^{\bar{x}}\left(\frac{1}{1-\delta}\right) x h(x) d x,
$$

which is strictly positive.

Under Assumption $1, \pi(x, z / p) \equiv \pi(x, x)$, so taking the derivative of the left-hand side of the incentive compatibility constraint with respect to $p$ yields

$$
\int_{z / v}^{z / p}\left(\frac{c z / p^{2}}{1-\delta}\right) h(x) d x+\int_{z / p}^{\bar{x}}\left(\frac{1}{1-\delta}-\frac{1}{1-\delta \pi(x, x)}\right) h(x) d x,
$$

which is also strictly positive (note that the $p$ appears in the limits of integration, but changes in these limits clearly cancel each other out.) Since the constraint is relaxed by increasing $p$, and the objective function is increasing in $p$, it must be that $p \leq v$ is a binding constraint, and so $p=v$.

When Assumption 1 is relaxed, an increase in $p$ need not relax the incentive constraint, so $p=v$ may not be optimal. But the solution to (3) is clearly not $m=\bar{x}$ since that implies profits are zero. And the solution is $m=0$ only if $\delta$ is sufficiently high and the incentive constraint does not bind (and recall that we assumed the incentive constraint fails to hold when $m=0$ ). If the incentive constraint is not satisfied at $m=0$ and $p=v$, but is satisfied at $m=\bar{x}$ and $p=v$, then clearly the solution must satisfy $m>0$. Note that when $m>0$ and $p<v$, then consumers for whom $x<p m / v$ are excluded, consumers for whom $x \in[m, \bar{x}]$ purchase $x$ units, and consumers for whom $x \in[\mathrm{pm} / v, m)$ purchase $m>x$ units and monitor more, so consumers who monitor poorly (i.e., $x<m$ ) are excluded when $x$ is low and are constrained to engage in more monitoring when $x$ is larger than $\mathrm{pm} / v$ but not greater than $m$. 